$\xi=-1$

\title{
The Intention of Accounting Students in Pursuing Professional Qualification
}

\author{
Maisarah Mohamed Saat ${ }^{1}$, Annur Azizah Ismail ${ }^{2}$, Noriza Mohd. Jamal ${ }^{3}$, Norhalimah Idris ${ }^{4}$, S. Ramakrishnan $^{5}$ \\ 1,2,3,4,5 Faculty of Management, Universiti Teknologi Malaysia \\ *Corresponding author E-mail: maisarahsaat@utm.my
}

\begin{abstract}
Malaysia still has a long journey to reach its mission that is to have 60,000 qualified accountants by year 2020. This scenario has motivated this study in examining the accounting students' intention to pursue accounting professional qualification. It also attempted to identify the differences in their demographic background and their intention in attaining such qualification. A total of 130 accounting students from a public university in Malaysia participated in this study and the modified survey questionnaire was distributed among them. The findings revealed that almost half of respondents were certain while the other half probably will pursue their professional qualification. ACCA, CIMA and ICAEW are top choices of professional qualifications. In general, the accounting students have good perceptions on the credibility of accounting profession. It is recommended that the educators and the professional bodies play their roles to encourage and motivate accounting students to pursue their professional qualification.
\end{abstract}

Keywords: Accounting students; Intention; Professional Qualification

\section{Introduction}

There is an evolution in accounting world and its education as the globalization and advancement of information technology had revolutionized the business environment in this twenty-first century (1). The changes that occurred in the environment of business as well as the economic condition indicate that the nature of duty of accountants have changed significantly $(2,3)$. According to Erlane \& Kamaruzaman, (1), this condition leaves the extremely indication for the educator especially Malaysian universities to play a big role in increasing the numbers of qualified accounting graduates as professional accountants.

Therefore, this study was conducted to identify the intention of accounting students in pursuing the professional qualification. The study was also conducted to investigate the perception of accounting students regarding the professional qualification and accounting profession. The subsequent Section 2 starts with the discussion of Theory of Planned Behavior (TPB) followed by the literature review. Section 3 explains the research methodology while Section 4 reports the analysis of findings. The paper then concludes and discusses the findings of the study.

\section{Literature Review}

There are extensive researches performed by Icek Ajzen and his co-authors regarding the human's intention. This study was guided by the Theory of Planned Behavior (TPB) introduced by (4). As cited from Ajzen (4), intention to do different kind of behaviors can be estimated with the high accuracy from attitudes toward the behavior, subjective norms and perceived behavioral control. The significant variance in actual behavior can be derived from the relationship of intention and perceptions of behavioral control.
The mechanism of TPB model is initiated when a person's behavioral intention (I) to execute the behavior (see Figure 1). Next, the behavioral intention is specified by three factors that pertaining the behavior in question. The factors that involved related to such behavior are attitude toward the behavior (A), which refers to the degree to which the person has a favorable or unfavorable evaluation of the behavior in question; subjective norm (SN), which refers to the perceived social pressure to perform or not to perform the behavior; and perceived behavioral control (PBC), defined as the ease or difficulty of performing the behavior. The common rule that was implied in this model is, the more favorable the attitude and subjective norm with respect to a behavior, and the greater the perceived behavioral control, the stronger an individual's intention to perform the behavior under consideration $(5,6)$. In other words, the stronger the intention to engage in a behavior, the more likely should be its performance (6). Therefore it is important to investigate the intention of pursuing professional qualification among accounting students.

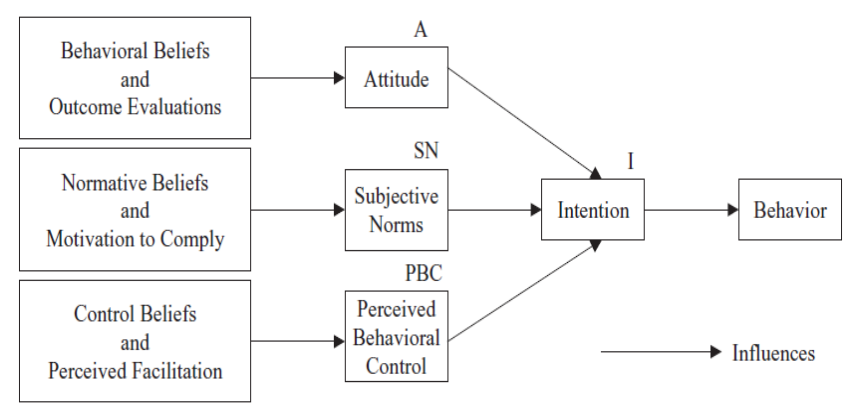

Fig.1: Theory of planned behaviour

Besides, there are also prior studies that identified multiple aspects of the decision 
made by students in choosing the accounting majors and it is more precise on pursuing career in accounting field $(2,7)$. In the articles of Hogue, et al., (8), they explained about the students' background differences and the implication of perception on the work as an accountant. All of these attributes will give huge contribution in decision making to pursue professional qualification in accountancy. Researcher revealed the job security and stability is one of the factors in considering in pursuing professional qualification, specifically by the female accountants (9).

\subsection{Perception about Professional Qualification and Accounting Profession}

It was proven based on the earlier studies that the perceptions and stereotypes that people had in themselves become the crucial factors that influencing their career decision (10). These discoveries were recognized by other researcher, (11) by giving a remark of ' how accounting is perceived by society affects whether or not the best and brightest students are attracted to the profession'. Correspondingly, (7) opined that the career choice was not only based on the students' perception but also the people's perception from their surroundings. Moolloy (12) claimed that the attitude of students toward the accounting profession was influenced by their perception. The researchers give a term to signify the students' attitudes as 'pre-entry attitudes'. According to the same researchers, the accounting profession was affected by expectation based on the societal stereotyping, childhood experiences and the imagery portrayed by this profession and students' experiences when they learnt about accounting at university level.

Samsuri, et al (13) and (14) have conducted studies on Malaysian accounting students in investigating their intention to pursue professional qualification and factors that may influence their intention. Samsuri et. Al (13) have found that accounting students want to pursue as they believe that it will enhance job opportunity especially during when the competition is tough. Similarly, Mustapha \& Abu Hassan (14) that job stability and security, opportunities for advancement and the students' perceptions towards the profession will significantly influence their decision to pursue professional examination. Mustapha \& Abu Hassan (14), however, discovered that responses towards the intention is not encouraging as about a quarter of the respondents were certain that they would pursue their professional qualification.

The perception towards accounting field and professional qualification are important in determining whether accounting students would pursue their professional qualification. Students in both studies by(13) and (14) have good perception on this. The perception that was mistaken by accounting students may lead to the wrong person that fills in the accountant's empty job position and the right person will grab another, alternative profession(7) Moreover, imprecise perceptions will result the individual to have job dissatisfaction in which it is unnecessary for the employment(15).

It was empirically tested by the previous researchers that people would choose their upcoming job partly based on the society's stereotypical representation of the mentioned career. Therefore, there is urgency where the students must have rational perceptions towards the accounting world and its job due to the fact that misleading representations can direct them to the distorted judgments(7). The next section discusses the methodology of research that was employed to achieve the objectives of this study.

\section{Methodology}

This research is quantitative in nature, using questionnaire to collect data from the respondents. The questionnaire was adapted from Mustapha \& Abu Hassan (14) and was slightly modified The respondents consist of third and final year accounting students from two cohorts. Each questionnaire was allocated to each student using direct face-to-face method. The population of third and fourth year students is 160 but only 130 sets of questionnaires were completed.

All the data that was gained from the questionnaire was gathered, managed and entered into the computer via Statistical Package for the Science Social (SPSS) Software version 20.0. The statistical analysis that was used to present the findings was divided into two major categories which are descriptive statistics (percentage, mean score, standard deviation, frequency counts and cross tabulation) and inferential statistics (Chi-Square test). This analysis is the non- parametric test that was performed to validate the findings from the descriptive analysis (cross-tabulation).

\section{Results and Findings}

All questionnaires were collected and analyzed by the researcher. The findings were elaborated and explained as follows:

\subsection{The Intention of UTM's Accounting Students in Pursuing the Professional Qualification}

The intention to pursue the professional qualification by accounting students can be identified in two ways which are via the categorical question as well as Likert-scale that were included in the questionnaire survey. Table 1 portrays the results regarding the students' intention in pursuing the professional qualification based on the categorical question (Question 6). The table was shown as follows:

Table 1: Intention to pursue professional qualification

\begin{tabular}{|c|c|c|}
\hline Intention & Frequency & Percentages (\%) \\
\hline Certainly & 56 & 43.1 \\
\hline Probably & 59 & 45.4 \\
\hline Unlikely & 15 & 11.5 \\
\hline
\end{tabular}

In Table 1 , it is found that almost one third of the respondents have the intention to pursue professional qualification. Almost half of the respondents are not sure whether they want to pursue or not since the answer indicates probably.

In addition, an item in the questionnaire (Item 19) that was stated in Table 4.17 which states 'I will pursue the professional qualification to become a professional accountant after graduating' shows the mean of 3.83. This finding was based on the data collected using 5 point Likert-scale (1-strongly disagree to 5-strongly agree) It signifies that on average the respondents are inclined to agree that they will pursue professional qualification.

Furthermore, there are several professional programs offered by the professional bodies all over the world such as Association of Chartered Certified Accountant (ACCA), Chartered Institute of Management Accountants (CIMA), Malaysian Institute of Certified Public Accountants (MICPA), Certified Practicing Accountants (CPA Australia), and Institute of Chartered Accountants in England and Wales (ICAEW). Among those who were 'certainly' and 'probably' (total 115) going to pursue their professional qualification, they were asked which professional program they have the intention to take. Table 2 reports the findings:

Table 2: Professional programs (in frequency)

\begin{tabular}{|l|l|c|c|c|}
\hline \multirow{2}{*}{} & \multicolumn{2}{|c|}{ Yes } & \multicolumn{2}{c|}{ No } \\
\cline { 2 - 5 } & \multicolumn{1}{|c|}{$\#$} & $\mathbf{\%}$ & $\#$ & \% \\
\hline ACCA & 93 & 80.9 & 22 & 19.1 \\
\hline CIMA & 28 & 24.3 & 87 & 75.7 \\
\hline MICPA & 10 & 8.7 & 105 & 91.3 \\
\hline CPA Australia & 8 & 6.9 & 107 & 93.1 \\
\hline ICAEW & 19 & 16.5 & 96 & 83.5 \\
\hline
\end{tabular}

Respondents were allowed to choose more than one responses. The results indicate that if the respondents were to pursue professional qualification, most of them will choose ACCA, followed by CIMA and ICAEW. 
From the findings, it can be seen that although the number of respondents who have intention to continue with accounting professional is not that encouraging, they are aware that they have the opportunities to do that; and if they do continue, they have more preference in doing ACCA as compared to others.

\subsection{Perception towards Professional Qualification and Accounting Profession}

A total of 36 items were chosen from previous research questionnaire in order to determine the perception of accounting students on accounting field and accounting professional qualification. Five point Likert-scale that was used in this study, from 1 (strongly disagree) to 5 (strongly agree). Data was analyzed to find their mean and standard deviation. The results of the analysis were tabulated as follows:

Table 3: Students' perception towards the continuation of study for having professional qualification

\begin{tabular}{|c|c|c|c|}
\hline No. & Item & Mean & $\begin{array}{l}\text { Std. } \\
\text { Dev }\end{array}$ \\
\hline 1. & $\begin{array}{l}\text { Professional qualifications are highly valued } \\
\text { by the public. }\end{array}$ & 4.39 & 0.63 \\
\hline 2. & $\begin{array}{l}\text { Accountants with professional qualifications } \\
\text { are more respected than accountants with } \\
\text { degree in accounting. }\end{array}$ & 4.29 & 0.78 \\
\hline 3. & $\begin{array}{l}\text { Professional titles are highly and international- } \\
\text { ly recognized. }\end{array}$ & 4.52 & 0.50 \\
\hline 4. & $\begin{array}{l}\text { Job as accountant is more flexible compared to } \\
\text { another professional job. }\end{array}$ & 3.18 & 1.03 \\
\hline 5. & $\begin{array}{l}\text { Job as accountant will confirm the job stability } \\
\text { compare to other professional career. }\end{array}$ & 3.59 & 0.94 \\
\hline 6. & $\begin{array}{l}\text { Career as accountant are highly secured (Job } \\
\text { Security). }\end{array}$ & 3.51 & 0.84 \\
\hline 7. & $\begin{array}{l}\text { Accounting field have better opportunity to } \\
\text { specialize. }\end{array}$ & 4.27 & 0.56 \\
\hline 8. & $\begin{array}{l}\text { Professional accountants will have better } \\
\text { opportunities for promotions to be in high } \\
\text { level position in a company. }\end{array}$ & 4.32 & 0.70 \\
\hline 9. & $\begin{array}{l}\text { Accounting field is the professional field that } \\
\text { provides better training opportunity. }\end{array}$ & 4.13 & 0.81 \\
\hline 10. & $\begin{array}{l}\text { Accounting field will guarantee the bright } \\
\text { future opportunities. }\end{array}$ & 3.91 & 0.86 \\
\hline 11. & $\begin{array}{l}\text { The professional accounting examination is } \\
\text { not tough and not so difficult to pass. }\end{array}$ & 2.73 & 0.93 \\
\hline 12. & $\begin{array}{l}\text { Accounting field is more interesting than other } \\
\text { professional fields. }\end{array}$ & 3.57 & 0.91 \\
\hline 13. & $\begin{array}{l}\text { Only students with an excellent cumulative } \\
\text { grade point aggregate (CGPA) can pursue } \\
\text { professional accounting exam. }\end{array}$ & 2.60 & 1.04 \\
\hline 14. & $\begin{array}{l}\text { Only those who have degree in accountancy } \\
\text { can pursue professional accounting exam. }\end{array}$ & 2.49 & 1.17 \\
\hline 15. & $\begin{array}{l}\text { Professional graduated is paid higher salary } \\
\text { than degree graduated. }\end{array}$ & 4.18 & 0.70 \\
\hline 16. & $\begin{array}{l}\text { High salary is my main factor why I choose to } \\
\text { pursue professional exam after I graduated. }\end{array}$ & 3.72 & 0.97 \\
\hline 17. & $\begin{array}{l}\text { I can gain high salary if I have professional } \\
\text { qualification. }\end{array}$ & 4.24 & 0.62 \\
\hline 18. & $\begin{array}{l}\text { Degree holders are paid less than professional } \\
\text { qualification holders. }\end{array}$ & 3.92 & 0.67 \\
\hline 19. & $\begin{array}{l}\text { I will pursue the professional qualification to } \\
\text { become a professional accountant after gradu- } \\
\text { ating. }\end{array}$ & 3.83 & 0.82 \\
\hline 20. & $\begin{array}{l}\text { Professional accountant will be my first priori- } \\
\text { ty in my career choice decision. }\end{array}$ & 3.72 & 0.96 \\
\hline 21. & $\begin{array}{l}\text { Career as professional accountant will be my } \\
\text { best interest. }\end{array}$ & 3.67 & 0.91 \\
\hline 22. & Professional exams scare me. & 3.74 & 1.00 \\
\hline 23. & $\begin{array}{l}\text { I like the challenges when taking professional } \\
\text { examination. I hope to pass all the profession- } \\
\text { al exams papers in one sitting. }\end{array}$ & 3.84 & 0.92 \\
\hline 24. & $\begin{array}{l}\text { It is not enough to have degree in accountan- } \\
\text { cy. }\end{array}$ & 3.90 & 0.95 \\
\hline 25. & $\begin{array}{l}\text { Professional qualification and non- } \\
\text { professional qualification are valued different- }\end{array}$ & 4.01 & 0.79 \\
\hline
\end{tabular}

\begin{tabular}{|c|c|c|c|}
\hline & ly by the public. & & \\
\hline 26. & $\begin{array}{l}\text { Work as accountant will guarantee the security } \\
\text { of the work. }\end{array}$ & 3.47 & 0.81 \\
\hline 27. & $\begin{array}{l}\text { Salary is my main factor in my career choice } \\
\text { decision. }\end{array}$ & 3.61 & 0.90 \\
\hline 28. & $\begin{array}{l}\text { Other professional fields are not stable com- } \\
\text { pared to accounting field. }\end{array}$ & 3.11 & 0.80 \\
\hline 29. & $\begin{array}{l}\text { Worker as banker is not flexible than works as } \\
\text { an accountant. }\end{array}$ & 3.13 & 0.75 \\
\hline 30. & $\begin{array}{l}\text { It is not difficult to get promotion in account- } \\
\text { ing. It is opportunities to specialize in account- } \\
\text { ing. }\end{array}$ & 3.48 & 0.80 \\
\hline 31. & I prefer accounting field than other fields. & 3.93 & 0.83 \\
\hline 32. & $\begin{array}{l}\text { Professional qualification holders are paid } \\
\text { better than degree holders. }\end{array}$ & 4.07 & 0.79 \\
\hline 33. & It is easy to pass the professional exam. & 2.70 & 1.01 \\
\hline 34. & Accounting field is fun to be around. & 3.61 & 0.88 \\
\hline 35. & $\begin{array}{l}\text { It is safer to pursue accounting program rather } \\
\text { than other program. }\end{array}$ & 3.50 & 0.74 \\
\hline 36. & $\begin{array}{l}\text { Training opportunities in accounting field is } \\
\text { better. }\end{array}$ & 3.82 & 0.73 \\
\hline
\end{tabular}

The analysis from Table 4.3 shows that students have the highest agreement on Item 3 (mean of 4.52), "Professional titles are high$l y$ and internationally recognized", and followed by Item 1 (4.39) "Professional qualifications are highly valued". This indicates that students have good perception on accounting as it is well recognized. Item 8, "Professional accountant will have better opportunities for promotions to be in high level position in company" have a mean of 4.32. This emphasizes that students choose to be in the accounting field and perceiving that this career promises a bright future as being a professional accountants will likely make them important personnel in the company.

Students also tend to agree to the statement "Accountants with professional qualifications are more respected than accountants with degree in accounting" (mean 4.29). They, therefore, agree that "Accounting field have better opportunity to specialize". These show that accounting students have good perceptions on the credibility of accounting profession and also its prospect.

In contrast, the lowest mean score is Item 28 "Other professional fields are not stable compared to accounting field". This shows that they are inclined to neither disagree nor agree about other professional field. Students in this study have shown their agreement that "Only students with the excellent cumulative grade point average (CGPA) can pursue professional accounting exam" (mean of 2.60). They also disagreed with the statement that says only accounting students can pursue accounting professional qualifications; this shows their awareness towards the opportunity and rights of pursuing professional qualification.

\section{Conclusion}

This study was conducted to identify the intention of UTM accounting students on pursuing professional qualification. Results show that almost half of the respondents have the intention to pursue their professional qualification. This result is more that the findings by(14) on similar objective. Meanwhile the other half of the respondents in this study was considering taking up the qualification. A small number responded that they do not have the intention at all.

Those who are certain in pursuing the professional qualification and those are considering or likely to pursue responded that they would like to take up ACCA, CIMA or ICAEW. This is probably because the professional bodies have made good exposure about their professional qualifications by reaching to the students. Frequent engagements made by these professional bodies such as seminar, briefing and exhibition have helped in making them recognized. The result is consistent with (14) who found that ACCA and CIMA were the top professional qualification students would choose if they were to pursue their professional qualification. 
It is also revealed that in this study, accounting students have good perception on the credibility of accounting profession. Interestingly, the findings of this study are closely similar to the findings of (14). In both studies the top two statements are ranked with high means. The two statements are, "Professional titles are highly and internationally recognized", and "Professional qualifications are highly valued". This is important as the Theory of Planned Behavior shows that with good attitudes (perceptions) towards professional qualification, then they would have the intention (behavior) to pursue. This belief is also consistent with the findings of (13). Nevertheless they still think that it is not easy to pass the professional exam.

Based on the findings, it is recommended that the educators and the professional bodies play their roles to encourage and motivate accounting students to pursue their professional qualification. They should also assist to increase the accounting students' confidence and motivation to pursue professional qualification. More specifically, the educators could utilize and familiarize materials used by the professional qualification modules to the students in order to prepare them in pursuing the qualification in the future. It is important to highlight that he results from this study cannot be generalized as this study was conducted only in a public university.

\section{References}

[1] Erlane KGJSNMN, Kamaruzaman J. The 21st century accounting career from the perspective of the Malaysian university students. Asian Social Science. 2008;4(8):73-83.

[2] Foong S-Y, Khoo C-H. Attitude, learning environment and current knowledge enhancement of accounting students in Malaysia. Journal of Accounting in Emerging Economies. 2015;5(2):202-21.

[3] Sugahara S, Hiramatsu K, Boland G. The factors influencing accounting school students' career intention to become a Certified Public Accountant in Japan. Asian Review of Accounting. 2009;17(1):5-22.

[4] Ajzen I. The theory of planned behavior. Organizational behavior and human decision processes. 1991;50(2):179-211.

[5] Hutaibat KA. Interest in the management accounting profession: Accounting students' perceptions in Jordanian universities. Asian Social Science. 2012;8(3):303-16.

[6] Nga JKH, Wai Mun S. The perception of undergraduate students towards accountants and the role of accountants in driving organizational change. Education + Training. 2013;55(6):500-19.

[7] Geiger Ma. The First Course in Accounting : Students' Perceptions and Their Effect on the Decision to Major in Accounting by The First Course in Accounting : Students Perceptions and Their Effect on the Decision to Major in Accounting. Journal of Accounting Education. 2000;18.

[8] Hogue M, DuBois CLZ, Fox-Cardamone L. Gender differences in pay expectations: The roles of job intention and self-view. Psychology of Women Quarterly. 2010;34(2):215-27.

[9] Violette GR, Chene DG. Factors Influencing Students' Choice of the Accounting Major. The CPA Journal. 2012;82(9):14-6.

[10] Dimnik T, Felton S. Accountant stereotypes in movies distributed in North America in the twentieth century. Accounting, Organizations and Society. 2006;31(2):129-55.

[11] Mbawuni J. Examining Students' Feelings and Perceptions of Accounting Profession in a Developing Country: The Role of Gender and Student Category. International Education Studies. 2015;8(6):9-23.

[12] Molloy M. What Influences Accounting Student's Attitudes towards the Accounting Profession-A North West Experience. Dissertation of Letterkenny Institute of Technology. 2009(July).

[13] Samsuri ASB, Arifin TRBT, Hussin SB. Perception of Undergraduate Accounting Students towards Professional Accounting Career. International Journal of Academic Research in Accounting, Finance and Management Sciences. 2016;6(3):78-88.

[14] Mustapha M, Abu Hassan MH. Accounting Students' Perception on Pursuing Professional Examination. International Journal of Education. 2012;4(4).

[15] Germanou T, Germanou E, Hassall T, Tournas Y. Students' perceptions of the accounting profession : a work values approach Students' Perceptions of Accounting Profession: Work Value Approach. Asian Review of Accounting. 2009;17(2):136-48. 